\title{
THE GROWTH OF WORLD TRADE: THE ROBUSTNESS OF THE EVIDENCE
}

\section{Paola L. Montero Ledezma}

\begin{abstract}
In this work we revisit the seminal paper "The growth of world trade: tariffs, transport costs, and income similarity" by S. Baier and J. Bergstrand published in the Journal of International Economics (2001). We develop a rigorous econometric analysis of the robustness of their results. While our findings support Baier and Bergstrand 2001's general conclusions, we provide refined evidence of the results. Under robust estimators, we show that the presence of outliers overestimated the effect of trade liberalization and underestimated the effect of income growth, as sources of world trade growth in the second half of the past century.
\end{abstract}

Keywords: Gravity Equation, Robustness, Outliers Detection.

DOI: $10.23881 /$ idupbo.017.2-1e 